\title{
Quando o repórter aparece na TV: o corpo e a voz da notícia no telejornalismo
}

\author{
Filipe Peixoto \& Flávio Porcello \\ UFRGS
}

E-mail: filipeixoto@gmail.com/flavio.porcello@ufrgs.br

\begin{abstract}
Resumo
Este artigo trata da atuação do repórter de TV, que, apesar de ser um dos principais narradores da televisão, se encontra à margem das pesquisas acadêmicas. $\mathrm{O}$ objetivo foi mapear os estilos do repórter sob uma perspectiva histórica, buscando identificar diferenças e permanências nos elementos visuais da passagem (ou vivo), termo que no jargão jornalístico se refere ao momento em que o repórter aparece na reportagem. Como referencial teórico, utilizam-se conceitos de Bourdieu (2011), Goffman (1985), Coutinho (2012), Gutmann (2012), entre outros autores. Foram analisadas 72 reportagens das primeiras décadas do telejornalismo

neas, totalizando 145 passagens. Os resultados apontam um aumento no uso de movimentos de câmera, assim como o repórter também está se movimentando mais. O enquadramento mais utilizado é o plano americano, mas o plano geral, em que o repórter aparece de corpo inteiro, se tornou mais usual. O tempo médio da passagem aumentou, a formalidade do figurino está sendo deixada de lado e o grafismo surge como elemento visual auxiliar do repórter. O trabalho ainda reafirma a importância do papel do repórter, que conduz a narrativa, confere credibilidade ao relato e estabelece um elo com a audiência.
\end{abstract} brasileiro e 73 reportagens contemporâ-

Palavras-chave: repórter; telejornalismo; televisão; performance; audiência.

\begin{abstract}
This paper investigates the performance of the TV reporter, that, despite being is excluded of researches. The goal one of the main narrators of television, torical perspective in order to identify
\end{abstract}

Data de submissão: 2016-05-09. Data de aprovação: 2016-05-30. 
differences and continuities in the visual elements of the piece to camera, a term that in the journalistic jargon refers to the moment the reporter appears on TV. As a theoretical framework, we use concepts of Bourdieu (2011), Goffman (1985), Coutinho (2012), Gutmann (2012), among others. We analyzed 73 reports from the first decades of Brazilian television and 72 current reports, totalizing 145 pieces to camera. The results show an increase in the use of camera movements, and the reporter is also doing more movements. The most widely used framework is the medium shot, but the wide shot, in which the reporter appears full body, became more common. The average time of pieces to camera increased, the formality of clothing is being left aside and the graphics appears as a visual element helping the reporter. The study also reaffirms the importance of the TV reporter, that leads the narrative, gives credibility to the report and establishes a link with the audience.

Keywords: reporter; broadcast journalism; television; performance; audience.

\section{Introdução}

- STE artigo insere o repórter de televisão no núcleo central da investigação _ científica, uma iniciativa ainda difícil de ser encontrada na pesquisa acadêmica. Em levantamento realizado em quatro bancos online brasileiros de trabalhos acadêmicos (Banco de Teses da Capes, Biblioteca Digital Brasileira de Teses e Dissertações, Biblioteca Digital de Teses e Dissertações da USP e Lume - Repositório Digital da Universidade Federal do Rio Grande do Sul), encontramos apenas doze trabalhos, a partir da busca da palavra "repórter" ou "reportagem" no título combinada com as palavras "telejornalismo" ou "televisão" em qualquer campo. Entre estes trabalhos, cinco foram realizados por pesquisadores de fora da área da Comunicação, como Antropologia, Letras e Artes.

Por meio da prática profissional, percebemos a relevância da presença do repórter diante da câmera, marcada principalmente pela gravação da passagem ou vivo ${ }^{1}$, termos do jargão jornalístico que se referem ao momento em

1. O termo técnico "vivo" é o mais utilizado no telejornalismo português. Já o termo "passagem" é característico do telejornalismo brasileiro, que também já usou outras nomenclaturas para se referir ao momento em que repórter aparece, como, por exemplo, termos associados à disposição da inserção na reportagem: "boletim de abertura", "boletim de passagem" e "boletim de encerramento" (Rezende, 2000). Neste artigo, será adotado o termo "passagem". 
que o repórter aparece na TV durante a reportagem. Trata-se de um momento da reportagem que precisa ser executado com esmero, para não conturbar a narrativa e, preferencialmente, para contribuir no desenvolvimento da história que está sendo contada. Para estudantes de jornalismo e também para jornalistas em início de carreira, um dos principais desafios é o desempenho diante da câmera, que pode despertar temor e insegurança. Exercer um domínio sobre suas performances e estabelecer uma relação de confiança e naturalidade com a câmera é condição para que o repórter de TV obtenha resultados produtivos.

Quando inserimos o telejornalismo em uma linha do tempo, é possível ver claramente a relevância da figura do repórter, que sempre esteve presente, não só por meio da voz que conduz a narrativa, mas também pelo corpo que se materializa diante da câmera para dar uma informação. Sob essa perspectiva histórica, verificamos a importância dada à aparição do repórter, o qual pode se apresentar de várias formas. Mas que formas são essas? Quais os códigos visuais que permanecem com o passar do tempo e o que mudou no modo com que o repórter de TV realiza uma performance para se comunicar com a audiência? São questões que pretendemos responder ao longo deste artigo, investigando os códigos visuais que fazem parte do momento em que o repórter aparece na TV, observando diferenças e permanências ao longo da história da televisão.

\section{O telejornal}

A diversificação de mídias e a pulverização do consumo do audiovisual, especialmente pela Internet, não retira da televisão seu papel hegemônico, com presença consolidada em $97 \%$ dos lares brasileiros ${ }^{2}$. A TV desempenha uma função de praça pública dos tempos atuais, "onde os assuntos do cotidiano são oferecidos ao público para que recolha dali os temas a serem discutidos nas rodas sociais nos dias seguintes" (Porcello; Ramos; 2012, p. 215). Nas rotinas produtivas do jornalismo, a televisão tem como seu componente fundamental o trabalho em equipe. A divisão de atribuições no telejornalismo praticamente anula a possibilidade de uma autoria exclusiva, já

2. Dado que faz parte da Pesquisa Nacional por Amostra de Domicílios (Pnad) de 2013, realizada pelo IBGE. Segundo o levantamento, o Brasil tinha 65,1 milhões de domicílios particulares permanentes, dos quais 63,3 milhões (97,2\%) possuíam televisão (Revista Exame, 2015, documento eletrônico não paginado). 
que uma reportagem é construída a muitas mãos, desde a concepção da pauta até a organização do conteúdo dentro do telejornal, passando ainda por outros atores, como repórteres, cinegrafistas, editores de texto, editores de imagem, entre outros.

Estar perto do acontecimento para poder falar sobre ele é uma prerrogativa do repórter de televisão. Depois de se aproximar do fato, compreendê-lo, captar as imagens e as entrevistas necessárias para construir uma história, ainda é preciso saber como apresentar a narrativa de modo que seja informativa, precisa e atrativa para o telespectador. Neste ponto, entra em ação uma característica que marca o texto no telejornalismo: a clareza da informação, uma busca pela inteligibilidade da maior parte da audiência.

A cultura profissional dos telejornalistas indica que o texto dito pelo repórter ou pelo apresentador deve ser simples, objetivo e, de preferência, escrito na forma direta (Becker, 2005). Nem sempre equilibrar a equação entre ser simples e ser raso é tarefa simples. "Escrever com simplicidade e construir um texto crítico e criativo é um constante desafio, pois as matérias, muitas vezes, tornam-se superficiais" (Becker, 2005, p. 73). Comprometido com a necessidade de ser compreendido pelo público, o jornalista adota muitas vezes um caráter pedagógico quando está informando. Se a proposta é introduzir um conceito que se parte do pressuposto que a maior parte da audiência não é familiarizada, a informação precisa ser abandonada ou se faz a opção pela explicação didática. Um exemplo é passagem da repórter de economia do Jornal Nacional da Rede Globo, Elaine Bast (Figura 1), que durante uma reportagem sobre a desvalorização doa moeda Real, exibida no dia 22 de setembro de 2015, utiliza um texto didático para explicar o tema:

O valor da moeda é reflexo da saúde de um país. Se a economia está forte, vigorosa, isso traz valor pra moeda, que também se fortalece. Mas quando a saúde dessa economia vai mal, a moeda fica fraca e perde valor. É exatamente isso que está acontecendo com o real (Jornal Nacional, 2015). 
Figura 1. Passagem de Elaine Bast, em 2015.

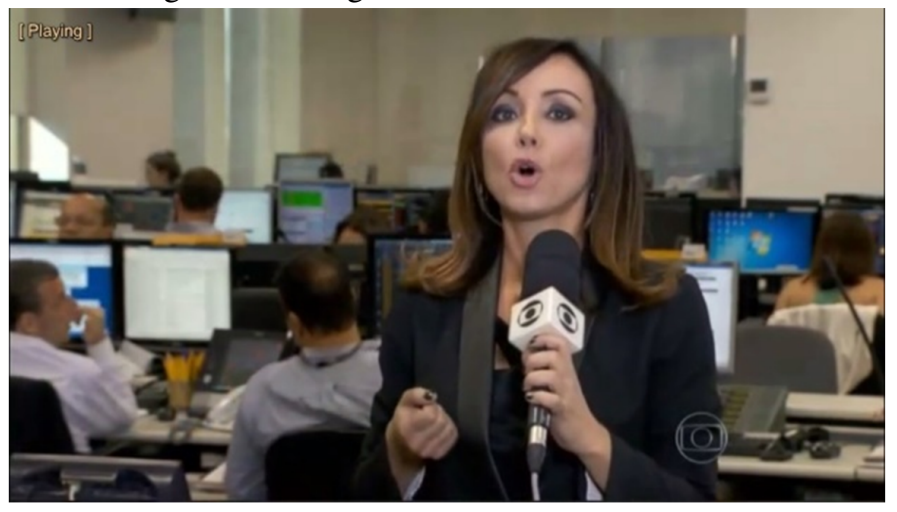

Fonte: Jornal Nacional, 2015.

Na passagem, a repórter está em um ambiente com pessoas e computadores, que pode ser associado ao mercado financeiro, e fala pausadamente, dando ênfase dramática nas palavras "forte" e "fraca". A eficácia da metáfora depende do perfil da audiência. Para alheios ao mundo da economia, será esclarecedor, enquanto o telespectador que já sabe o significado de desvalorização monetária pode considerar a comparação desnecessária e até mesmo pobre de informação. Esses questionamentos, em maior ou menor escala, sempre acompanham os jornalistas de televisão, que precisam presumir uma audiência para fazer escolhas sobre como organizar seu discurso.

A esse exercício de antecipar um telespectador para o jornalista embasar decisões profissionais, Alfredo Vizeu (2005) chama de "audiência presumida", conceito que oferece grande contribuição para pensar o telejornalismo sob a ótica do campo da produção. A premissa é de que os jornalistas constroem uma imagem do telespectador para o qual falam a partir de suposições pessoais e de construções alimentadas pela cultura profissional. Trata-se de uma imagem que não sabemos dizer se corresponde à audiência verdadeira, mas que mesmo assim exerce influência nas decisões tomadas para produzir a notícia.

O exercício de prever antecipadamente um público que vai assistir a reportagem está presente nas rotinas produtivas do repórter, desde a escolha das fontes até a escrita do texto final. Na gravação da passagem, a audiência 
também se faz presente na construção do texto que será apresentado, seja ele memorizado ou dito de improviso. O repórter olha para a câmera como se olhasse para o público que o assiste, e enuncia um discurso em que considera o universo que presume estar presente diante da televisão.

Ao transformar em ação o ato de mediar a informação para o público, o repórter utiliza recursos de dramaticidade, como a exploração da expressividade do corpo e da voz, aliada ao conteúdo da fala. A transmissão da informação exige uma capacidade de interpretação, articulando corpo, voz, cenário e texto memorizado, habilidade típica de um ator. Sobre a gravação da passagem, Pinto (1997) destaca que o repórter de televisão precisa ter capacidade de concentração para que as pessoas ao redor não atrapalhem. A passagem precisa contribuir para o enredo da reportagem, e o "resultado deve ser uma historinha com começo, meio e fim, contada a um público muito exigente, sempre disposto a ir embora (trocar de canal) caso o 'espetáculo' não lhe agrade" (Pinto, 1997, p. 01).

O sociólogo canadense Erving Goffman (1985) estuda o comportamento dos indivíduos no cotidiano com alusões às técnicas teatrais, considerando que é preciso incorporar papéis, expressões e gestos para que se possa exercer melhor controle sobre as impressões dos interlocutores. Assim, o indivíduo representa papéis com o intuito de socializar e buscar os melhores resultados dentro de cada tipo de representação. "Quando um indivíduo se apresenta diante de outros, terá muitos motivos para procurar controlar a impressão que estes recebem da situação" (Goffman, 1985, p. 23). O autor postula que é possível dividir o que se vê em duas partes: "uma, que o indivíduo facilmente manipulará quando quiser, constituída principalmente por suas afirmações verbais, e outra, em relação à qual parece ter pouco interesse ou domínio, oriunda principalmente das expressões que emite" (p. 16). Sob essa perspectiva, podemos afirmar que não somente o texto do repórter influi na percepção do telespectador, mas também as expressões e a comunicação corporal, as quais compõem os significados apreendidos pelo interlocutor.

Apesar de cada repórter ser dotado de bagagens diversas e entendimentos próprios de direcionamento da reportagem, a presença dele no vídeo respeita uma linguagem estética que, por convenção, é compartilhada pelo grupo social de telejornalistas. Essa estética sofre tensionamentos, seja do formato do telejornal em que está inserido (mais tradicional, mais informal, mais policial), do estilo do repórter (mais sério, mais descontraído, mais ousado) e da 
própria pauta, que pode ser de um assunto mais leve e fácil de exercer criatividade, ou um tema mais duro, que dificulta a elaboração de uma intervenção diferenciada do repórter. De qualquer forma, a passagem nunca é meramente uma construção individual e sem historicidade, já que carrega uma série de simbolismos e convenções internalizadas por repórteres e cinegrafistas. As decisões tomadas em campo, tanto em relação ao texto falado quanto à performance diante da câmera, estão inseridas num universo de possibilidades já instituído pelo próprio campo do telejornalismo.

Ao observar a reportagem de televisão, Gutmann (2012) postula que nos telejornais atuam sujeitos sociais que se implicam nos relatos, fazendo do seu corpo um lugar de personificação da notícia. Para a autora, o repórter não é percebido tão somente como um dos sujeitos sociais, e sim como o elemento central no processo de autenticação dos relatos, ao representar a presença simbólica da emissora de televisão no lugar e na duração temporal do acontecimento. A autora aponta que o repórter se constrói como um ser social que vive os fatos e, portanto, está autorizado a falar sobre eles.

Coutinho (2012) analisa a informação na TV propondo um paralelo entre notícia e drama, sem se deixar perturbar por associações precipitadas que poderiam relacionar essa aproximação com entretenimento e sensacionalismo. A intenção é entender as narrativas do telejornalismo como histórias que possuem início, meio e fim, onde é possível perceber conflitos que impulsionam seu desenvolvimento diante dos olhos do telespectador. A forma como a notícia é apresentada nos telejornais e o uso de personagens diversos para construir a narrativa também lembram os recursos da dramaturgia.

A encarnação de papéis é uma constante no cotidiano dos indivíduos, jornalistas ou não. Seguindo a analogia com a prática teatral, Goffman divide todo indivíduo em dois papéis: ator e personagem. Ao ator, cabe a função de constantemente representar, de acordo com o ambiente, a plateia e seus objetivos pessoais, "um atormentado fabricante de impressões envolvido na tarefa demasiado humana de encenar uma representação" (Goffman, 1985, p. 270). Já os personagens representados, que podem ser inúmeros para cada ator, são tipos idealmente fabricados para os propósitos da ocasião, "tipicamente uma figura admirável, cujo espírito, força e outras excelentes qualidades a representação tinha por finalidade evocar" (Goffman, 1985, p. 270). Cada papel, tanto ator quanto personagem, tem sua importância dentro do espetáculo do cotidiano que precisa prosseguir. 


\section{O repórter}

Cada indivíduo é um potencial narrador e multiplicador de suas próprias narrativas, um distribuidor independente de suas subjetividades. Em meio a múltiplas vozes, está o discurso jornalístico, que se diferencia dos demais por suas especificidades. Todos os dias, os repórteres de televisão narram histórias que ajudam a retratar a sociedade, com o compromisso, idealmente falando, de informar, contextualizar e ajudar o público a entender o mundo onde vive. Em 1936, o filósofo alemão Walter Benjamin escreve um ensaio em que propõe uma visão própria sobre a narrativa. Na época, a televisão vivia seus primórdios, no entanto o autor faz ponderações que permanecem atuais. Segundo Benjamin (1996), "a experiência que passa de pessoa a pessoa é a fonte a que recorreram todos os narradores", e o autor, ainda com foco nas narrativas escritas, destaca um estilo que, para ele, tem mais eficiência: "as melhores (narrativas) são as que menos se distinguem das histórias orais contadas pelos inúmeros narradores anônimos" (p. 198). A televisão veio a reforçar esse entendimento, incorporando na sua linguagem o estilo informal de comunicar.

Benjamin cita a função utilitária do narrador, que deve ser um homem que sabe dar conselhos. "Essa utilidade pode consistir seja num ensinamento moral, seja numa sugestão prática, seja num provérbio ou numa norma de vida" (1996, p. 200). O narrador faz uma pré-organização da história que vai contar, posicionando-se a partir de um lugar de fala e tomando decisões que interferem no resultado final do trabalho. Ao executar seu ofício, "seleciona algumas coisas e não outras; enfatiza umas, mas não outras; prefere alguns personagens a outros" e "por mais que ele tente dissimular as marcas da sua enunciação elas estão sempre lá e precisam ser apreendidas, assim como o fazemos num texto escrito" (Rossini, 2006, p. 115).

Benjamin (1996) destaca a função dos narradores, que possuem uma tarefa que não se limita a repassar um relatório de informações, como se fosse possível transmitir o estado puro das coisas. O labor se dá em mergulhar "a coisa na vida do narrador para em seguida retirá-la dele", e assim, torna-se possível imprimir na história a marca do narrador, "como a mão do oleiro na argila do vaso" (p. 205). Tal associação serve bem ao trabalho do repórter de televisão que, além de transmitir a informação, precisa impregnar o relato 
com suas impressões e experiências, aproveitando o estado de copresença para cativar o público e se tornar uma pessoa bem-vinda ao lar do telespectador.

As pesquisas acadêmicas em telejornalismo, ao se proporem a estudar as personas dos programas noticiosos, têm escolhido como objeto preferencial das análises os apresentadores de TV, que são vistos com autoridade suprema, cabendo a eles o ofício de "abrir a cena diária por onde desfila a sociedade com seus bons e maus exemplos", assim como "fechar as cortinas do espetáculo, em geral com sorriso nos lábios pronunciando 'Boa-noite, até amanhã'." (Porcello, Ramos, 2012, p. 216-217). Este artigo busca contribuir com um equilíbrio, direcionando a pesquisa para o repórter, um agente de produção da notícia que tem grande potencial de imprimir marcas de autoria no seu trabalho. As histórias contadas pelos repórteres não são formadas apenas pelas palavras e imagens escolhidas pela equipe, mas também pela forma como o conteúdo é transmitido pelo corpo repórter.

Para Rosário (2004), não há comunicação sem corpo, que pode ser entendido nessa perspectiva como um meio básico de expressão humana, uma mídia primária. Os corpos ocupam os espaços físicos e também os midiáticos, tornando-se assim corpos eletrônicos, capazes de gerar significados, produzir mensagens e realizar trocas simbólicas. Na interação entre indivíduos, Goffman (1985) destaca que o essencial é ser acreditado pelo outro enquanto personagem em representação, independentemente se aquele que representa está convencido de seu ato ou cínico em relação a ele, ciente de que nem toda sua representação condiz com a realidade. O grupo observador, que no telejornalismo seria representado pela audiência, pode "perceber que o indivíduo está manipulando o aspecto supostamente espontâneo de seu comportamento e procurar no próprio ato da manipulação alguma variação da conduta que o indivíduo não tenha conseguido controlar" (Goffman, 1985, p. 20). Essa desconfiança faria o observador migrar da crença para a descrença perante a representação. Para executar a tarefa diária de ser acreditado pelos demais indivíduos, o corpo desempenha um papel chave, já que são as suas manifestações que vão compor um "texto que busca produzir credibilidade, manifestada na combinação complexa de traços e marcas que se expressam no rosto, no vestuário, no modo de andar, nos gestos, na postura, no uso dos espaços" (Rosário, 2009, p. 05).

O repórter interpreta corporalmente o dito, explora expressões faciais, gestualidades, proximidades e distanciamentos da tela. "Se antes a regra era 
apresentar-se enquanto ventríloquo do fato, hoje o corpo do repórter também é explorado como lugar de performatização do acontecimento narrado" (Gutmann, 2012, p. 126). Quando a câmera liga e o repórter inicia sua mediação, o jornalista se readéqua enquanto corpo eletrônico narrador dos acontecimentos. Em cena, não se encontra um indivíduo desprovido de intencionalidades e de influências da cultura profissional, mas sim um sujeito midiático que se comporta conforme gramáticas audiovisuais compartilhadas pelo seu grupo: "cuidado maior com a aparência, olhar para a câmera, gesticulação contida, objetividade e rapidez na expressão verbal, poucos movimentos na expressão facial" (Rosário; Damasceno, 2014, p. 179). O texto corporal do repórter não é o mesmo que ele usa para as tarefas rotineiras, mas sim uma representação midiatizada pensada para $\mathrm{o}$ ato enunciativo diante da câmera.

Na representação diante da câmera, o corpo eletrônico do repórter tende a reproduzir os mesmos formatos e recursos expressivos, já comuns dentro do seu grupo. Estamos falando de um corpo prescrito, padronizado, em que o narrador "se submete à imposição das gramáticas para articular seus discursos e fundamentar seus textos principalmente sobre o poder e o saber, sustentados pela força e pela lógica" (Rosário, 2009, p. 10). No entanto, é justamente na forma com que o sujeito televisivo articula os formatos hegemônicos que ele pode encontrar um caminho para a autoria. Se estamos lidando com corpos padronizados, são pelas brechas de performance que o narrador pode imprimir suas marcas de autor, recorrendo à clássica definição de Benjamin (1996) sobre o papel do narrador, de mergulhar a coisa narrada em si mesmo para depois colocar para fora.

O pesquisador Antonio Brasil, que atuou como repórter cinematográfico, afirma que "após mais de 50 anos de grandes realizações, o velho modelo de produção televisivo apresenta sinais evidentes de desgaste, se tornou repetitivo, pouco criativo" (Brasil, 2012, p. 115). Os modelos de produção persistem nem tanto por teimosia, mas em prol do funcionamento de um sistema que precisa produzir notícia a todo momento e necessita criar processos que deem conta de alimentar as programações noticiosas de milhares de emissoras de TV no mundo. Dentro das redações, o próprio modo de fazer convencional se perpetua por meio da referência que os profissionais recém-chegados têm nos mais experientes, que carregam maior bagagem normativa.

As instruções sobre como se portar diante da câmera, quais informações apresentar e como dizê-las podem ser aprendidas na formação acadêmica do 
jornalista, em treinamentos promovidos pelas empresas ou na prática, por meio da observação daqueles já acostumados com um modus operandi, que perpetua velhos modelos. Para Brasil (2012), o repórter frequentemente aprende como se portar com o cinegrafista, "o verdadeiro professor para os jovens e não tão jovens jornalistas que se iniciam no telejornalismo" (p. 179). Apesar de ser protagonista na construção estética no telejornalismo, o cinegrafista é pouco estudado no meio acadêmico. A exclusão da categoria das pesquisas não deixa de ser um eco da falta de reconhecimento do profissional no mercado de trabalho. Por mais que um repórter esbanje talento na hora de performar, a relação da câmera com o acontecimento tem prioridade. A matéria-prima de uma narrativa televisiva depende da capacidade do cinegrafista de captar o fato com qualidade, precisão, agilidade e, em muitos casos, poesia.

Ramos (2012), que na sua obra analisa a relação do espectador com a imagem-câmera nas diversas situações do cotidiano, afirma que a câmera não existe por si só, há um sujeito concreto que está apertando o botão. No telejornalismo, trata-se do cinegrafista, parceiro diário do repórter, com quem divide tarefas, desafios e decisões de como mostrar o acontecimento. Tão importante quanto a decisão do que dizer ou mostrar na reportagem, é a forma com que serão mostradas as imagens audiovisuais, como por exemplo, os tipos de enquadramentos, o uso ou não de um movimento de câmera, o tempo destinado para cada tomada, entre outros. Da mesma maneira, o repórter, além de definir o texto que será dito, precisa decidir como será dito, qual o emprego de seu corpo na narrativa, que expressões faciais vão ser acionadas durante a gravação e até mesmo a escolha do figurino, que ajuda a compor um significado para o ato comunicativo.

A forma do repórter se comunicar com a audiência passa, necessariamente, pela atuação ativa do cinegrafista, profissional que decide como dispor os elementos visuais em cada plano. A postura estética que repórter e cinegrafista adotam também é política, porque se posiciona dentro de uma linguagem, seja a reproduzindo ou a desconstruindo. Esses dois profissionais, parceiros nas rotinas profissionais, também são potenciais agentes da mudança, ainda que estejam inseridos em uma lógica difícil de ser contrariada. 


\section{A passagem}

No telejornalismo, o repórter se encontra em um eixo central de mediação. Em uma esfera restrita ao universo profissional, podemos afirmar que ele precisa agenciar anseios e expectativas dos colegas de trabalho que anteveem a reportagem (produção) e aqueles que a finalizam (edição) para exibição, assim como mediar as diversas vozes que serão ouvidas ao deixar a redação para captar imagens e entrevistas que farão parte da reportagem. Sob uma perspectiva abrangente, o repórter também faz a mediação entre a instituição televisão e a sociedade para qual reporta. Para Machado (2000), o repórter goza de grande autonomia, por estar na fronteira intermediária entre a voz institucional e a voz individual, desempenhando uma espécie de interface entre a televisão e o evento.

Por ser uma construção discursiva de razoável complexidade, é comum as decisões sobre como se dará a participação do repórter sejam pensadas e discutidas entre os colegas, como produtores, cinegrafistas e editores. Imbuídos nas rotinas profissionais que instrumentalizam o indivíduo no desempenho das tarefas, os repórteres se valem de modelos para compor sua performance diante do vídeo. Esses formatos são construídos historicamente por meio de um modus operandi, um modo de fazer impregnado nas rotinas dos repórteres de televisão, construído e modificado ao longo da história do telejornalismo.

Esse modus operandi a que nos referimos tem respaldo na teoria do sociólogo francês Pierre Bourdieu (2011), que enxerga o mundo social através de campos - espaços simbólicos diversos, onde agentes fazem parte, operam, ditam regras e formam uma rede de valores constitutivos. A noção de campo é complementada por outros três conceitos desenvolvidos por Bourdieu, que de forma sintética pretendemos apontar. O primeiro deles é o "capital", que corresponde a um tipo de moeda que tem valor de acordo com as representações dentro de um campo. Aqueles que têm mais poder dentro do campo naturalmente possuem mais capital. Bourdieu, na sua obra, cita quatro tipos principais de capital: o cultural, o social, o econômico e o simbólico. O próximo conceito é de "habitus", que corresponde às regras do jogo empreendidas dentro de um campo, um "princípio gerador de estratégias inconscientes ou parcialmente controladas tendentes a assegurar o ajustamento às estruturas de que é produto tal princípio" (Bourdieu, 2011, p. 160). O terceiro conceito é illusio, uma forma específica de interesse que os agentes sociais possuem 
em participar do jogo, acreditando que a questão social que está posta dentro do campo é tão importante que vale a pena ser seguida.

Os conceitos de habitus e illusio nos ajudam a pensar os bastidores da execução de uma passagem, o objeto empírico do presente estudo. A partir da observação das participações dos repórteres na atualidade e nas primeiras décadas da televisão brasileira, como será demonstrando ao longo deste trabalho, é possível perceber através das imagens as regras que operam em cada tempo. O investimento de cada profissional em atender a essas expectativas - ou seja, o illusio - e o esforço do repórter em estar inserido dentro de uma linguagem para que seja reconhecido pelos demais integrantes contribuem para a manutenção de padrões, características comuns no modo do repórter se comunicar com sua audiência.

Toda passagem tem em comum três elementos básicos: um repórter, um dizer e um lugar. Tirando uma das bases desse tripé, dificilmente podemos falar que se trata de uma passagem. O repórter de TV precisa cumprir um ritual, em que gravar a passagem é uma das etapas. A legitimidade das coberturas em televisão tem como alicerce a presença de um jornalista no local onde ocorrem os fatos, seja em um espaço geográfico ou simbólico (Gutmann, 2012). O corpo do repórter in loco, na entrada ao vivo ou na reportagem gravada, agrega um peso simbólico de autenticidade ao relato.

Ao analisar a passagem, Abreu e Lima (2010) formula sete categorias, criadas a partir dos usos mais frequentes da passagem, num esforço de estabelecer funções sintáticas dentro de uma gramática do telejornalismo. A passagem de (1) contextualização de informações retoma acontecimentos ou relaciona circunstâncias que ajudam a compreender melhor a notícia. Na categoria (2) desdobramento do fato/fenômeno, o repórter desdobra informações, atualizando, fazendo previsões, repercutindo ou detalhando. A passagem de (3) indicação ou realce de percurso dá pistas do caminho que o repórter está seguindo para relatar a história, e pode servir como ponte entre elementos da narrativa. Na categoria (4) hierarquização de informações, a passagem ajuda a organizar situações ou personagens, atribuindo importâncias aos elementos da história. Na passagem de (5) proposição de juízos interpretativos, como o nome já diz, o repórter emite um juízo sobre o fato noticiado de forma crítica e analítica, onde pode apresentar uma conclusão mais explícita sobre o que foi explanado, podendo influenciar na formação dos juízos do telespectador. As passagens de (6) presentificação reforçam a condição de testemunha do 
repórter, destacando a proximidade dele em relação ao fato reportado. Por último, temos a categoria (7) gerenciamento de atenção, em que o repórter utiliza estratégias para despertar um maior interesse do telespectador.

A busca por categorizar as funções da passagem é um primeiro passo para fugir das normatizações tão comuns em manuais de telejornalismo. Entendemos que é preciso relativizar as regras, problematizar as práticas profissionais e mostrar como se faz aquilo que é feito, para permitir aos narradores, que atuam como repórteres, criarem, ousarem e buscarem outras e melhores formas de contar histórias, em vez de se preocuparem em seguir receitas préestabelecidas.

\section{Mapeando estilos}

$\mathrm{Na}$ busca por mapear estilos predominantes da passagem, decidimos observar não só a produção contemporânea, mas também os primeiros registros do telejornalismo. Para sistematizar as informações apreendidas pela observação do objeto, adotamos a Análise de Conteúdo, um conjunto de instrumentos metodológicos em constante aperfeiçoamento, que concilia o rigor da objetividade e a fecundidade da subjetividade (Bardin, 2011). Para executar a pesquisa seguindo os preceitos da Análise de Conteúdo, operamos em três etapas principais: pré-análise; exploração do material; tratamento dos resultados e interpretação.

Na pré-análise, organizamos as ideias por meio da escolha dos documentos a serem observados, da formulação dos objetivos e criação de indicadores que serviram de referência para a interpretação final. O primeiro contato foi feito por meio de uma leitura flutuante, quando o pesquisador observa o objeto com uma visão aberta, permitindo captar de maneira intuitiva dados e informações para embasar as decisões posteriores. Dividimos a leitura flutuante em duas etapas: passado e presente. Para observar a participação do repórter nas primeiras décadas da televisão, buscamos na Internet o máximo de canais possíveis para assistir a vídeos antigos do telejornalismo brasileiro. Notamos que são raros os espaços online para esse tipo de material, com ex- 
ceção do portal Memória Globo, lançado em $2008^{3}$, que foi escolhido como fonte documental de passagens antigas.

No segundo momento da leitura flutuante, pesquisamos as reportagens com potencial para representar a produção contemporânea. Durante três meses, observamos de forma aleatória as passagens de repórteres dos principais telejornais das quatro emissoras brasileiras de maior audiência ${ }^{4}$ : Globo, Record, Band e SBT. Nessa etapa, foi possível identificar uma homogeneidade nos formatos de passagens entre as quatro emissoras, sem que uma se destacasse da outra na forma como o repórter aparece no vídeo. Desse modo, optamos por escolher como fonte o Jornal Nacional ${ }^{5}$, telejornal de referência no país ${ }^{6}$ e detentor consolidado dos maiores índices de audiência.

3. A equipe do Memória Globo é formada por jornalistas, historiadores e antropólogos ligado a Rede Globo. Como exemplo dos principais conteúdos, podemos citar que o portal sistematiza a história da emissora, organiza as coberturas do telejornalismo por períodos e temas, produz webdocumentários sobre temas considerados relevantes para a empresa, e disponibiliza perfis dos principais profissionais do canal, onde predominam nomes de jornalistas, atores e apresentadores de programas (Memória Globo, 2015).

4. De acordo com as médias de audiência semanal divulgadas pelo Instituto Brasileiro de Opinião Pública e Estatística (Ibope). Os dados estão disponíveis no site https://www. kantaribopemedia.com.

5. O Jornal Nacional estreou em $1^{\circ}$ de setembro de 1969 . Foi o primeiro telejornal transmitido em rede nacional no Brasil, lançado para competir com o repórter Esso, da TV Tupi, e inspirado nos telejornais em rede que já existiam nos Estados Unidos. A primeira equipe do telejornal começou a desenvolver o conceito de noticiário nacional, até então pouco empregado na época. O desafio era não supervalorizar uma região em detrimento da outra, tarefa que até hoje é difícil de ser aplicada, já que as sedes principais das grandes emissoras do país se encontram no eixo São Paulo e Rio de Janeiro, somando-se a isso o peso do noticiário político que parte da capital federal. No entanto, pelo menos a ideia original era que as reportagens "deveriam ser de interesse geral e não regionais ou particularistas", sendo que os temas deveriam "chamar a atenção tanto do telespectador de Manaus quanto de Porto Alegre" (Memória Globo, 2004, p. 39). Atualmente seus apresentadores são William Bonner, que também exerce o cargo de editor-chefe, e Renata Vasconcellos, que acumula a função de editora-executiva. A exibição é de segunda a sábado, com início em torno de $20 \mathrm{~h} 30$ e duração aproximada de 45 minutos.

6. Os meios de comunicação de referência são, segundo Zamin (2014), "instituições que colocam em circulação elementos simbólicos a partir do vínculo e interação que estabelecem com o sistema social” (p. 936). De acordo com a autora, há diversos atributos associados ao jornalismo de referência, como tradição, credibilidade e seriedade. O jornalismo de referência tem como locus de observação preferencial áreas que envolvem o espaço público, Economia, Política e Relações Internacionais. Na maioria dos casos, o jornalismo de referência também é associado a índices elevados de audiência ou circulação. 
Com o universo demarcado, é preciso constituir um corpus, "conjunto dos documentos tidos em conta para serem submetidos aos procedimentos analíticos" (Bardin, 2011, p. 126). Para representar o modo com que o repórter performava no vídeo nas primeiras décadas do telejornalismo, foram captadas do portal Memória Globo todas as passagens em reportagens veiculadas até 1990, totalizando 73 inserções. O recorte tem início no ano de 1969, com uma reportagem sobre o lançamento do Apolo 11, que levaria o homem à lua. Para representar a produção contemporânea, escolhemos de forma aleatória os meses de setembro e outubro de 2015 e adotamos a semana composta para definir os dias de análise. Demarcamos uma semana inicial, de onde analisamos a edição de segunda-feira, depois separamos a edição de terça-feira da segunda semana, a edição de quarta-feira da terceira semana, assim sucessivamente até chegar ao sábado, completando seis edições. Seguindo esses critérios, analisamos as edições do Jornal Nacional dos dias 14, 22 e 30 de setembro, e 08,16 e 24 de outubro de 2015 , totalizando 72 passagens.

O mapeamento pretendido tem como guia os elementos visuais presentes nos momentos em que o repórter aparece no vídeo, resultado de uma série de fatores da cultura profissional e das intencionalidades dos atores que atuam na execução da reportagem, como explicamos ao longo desta investigação. $\mathrm{O}$ objetivo foi identificar diferenças e permanências sob uma perspectiva histórica no modo com que o repórter performa diante do vídeo no telejornalismo brasileiro, tendo como enfoque a imagem.

Após a captação das 145 passagens que integram a amostra, partimos para a elaboração de indicadores que fundamentem a interpretação final. Para isso, estabelecemos seis categorias para análise, com base nos referenciais teóricos e nas percepções obtidas durante a leitura flutuante do corpus da pesquisa: movimento de câmera; enquadramento; duração da passagem; movimento do repórter; uso da gravata e uso de grafismo. A maioria dos indicadores trabalha com a frequência de aparição do índice, ou seja, quanto mais vezes aparece, mais importância possui.

\section{Câmera em movimento}

Apesar de o cinegrafista ser o principal responsável pela imagem, sabemos que a decisão sobre o uso de movimento de câmera na passagem parte de um acordo mútuo entre repórter e cinegrafista, muitas vezes combinado 
com o ambiente onde estão inseridos e os elementos que se pretende destacar na participação do repórter. Segundo Gutmann (2012), as equipes dos telejornais utilizam os movimentos de câmera como "dispositivos enunciativos de aproximação, inclusão, distanciamento e ênfase argumentativa" (p. 110). Para Nogueira (2010), a utilização recorrente de um determinado código visual permite identificar padrões estilísticos que possibilitam o entendimento de aspectos históricos, escolas e tendências. Deste modo, uma análise mais atenta é útil para identificar nas imagens em movimentos exemplos de ruptura ou indicativos de uma tradição visual.

Quantificamos a frequência do uso de movimentos de câmera no momento da participação do repórter, sem estabelecer diferenciação entre os tipos de movimento, sendo apenas identificado se ocorreu ou não o movimento. Entre as passagens históricas, houve o predomínio da câmera parada, utilizada em $68 \%$ das passagens, contra apenas $32 \%$ de inserções com movimento. Nas passagens contemporâneas, a situação ficou mais equilibrada, ainda assim com a frequência maior de câmera parada, em 54\% dos casos, contra $46 \%$ de incidência de movimentos de câmera.

Apesar de verificarmos, por meio dos resultados, que na atualidade a câmera está menos presa a uma rigidez estética que a imobiliza, ainda percebemos o predomínio do quadro parado. Uma passagem de 1980, exibida pela Rede Globo, serve de ilustração para o apego que existia nas primeiras décadas do telejornalismo à câmera parada. $\mathrm{O}$ então correspondente internacional da emissora Roberto Feith, durante cobertura sobre a guerra entre Irã e Iraque, grava uma passagem em uma localidade em território iraniano ocupado. O repórter enfatiza que a recusa do cessar-fogo aumenta o número de cidade iranianas ocupadas pelo exército do Iraque, que acabam por ser abandonadas pela população. Ao fundo é possível identificar um caminho semelhante a uma rua e algumas casas de concreto desabitadas (Figura 2). Mesmo com o texto do repórter fazendo referência à cidade onde ele está e o aspecto de abandono da região, a câmera permanece imóvel, sem fazer um movimento que permitiria ao telespectador ter uma dimensão melhor daquele ponto da cidade, assim contribuindo para ilustrar com mais amplitude a informação destacada pelo repórter no local dos acontecimentos. 
Figura 2. Passagem de Roberto Feith, em 1980.

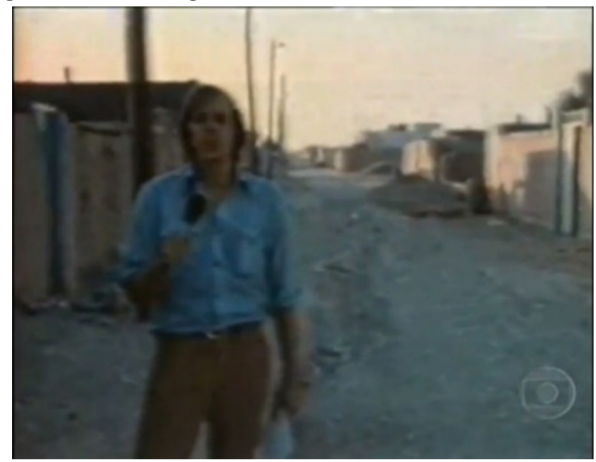

Fonte: Memória Globo, 1980.

Entre as passagens contemporâneas, há exemplos em que todo o movimento da cena depende exclusivamente da câmera. É o caso de uma passagem de Ricardo Soares, exibida em 16 de outubro de 2015, dentro de uma reportagem sobre a possibilidade de se trocar dívidas caras por mais baratas, como por exemplo, fazer a portabilidade de uma dívida de um banco com juros altos para outro com juros menores. Apesar de a reportagem ser construída com imagens de bancos, papéis, dinheiro e entrevistados, o local da passagem destoa, mas ganha sentido quando se compreende a analogia do texto do repórter. Ele está em um ambiente onde são vendidos legumes e frutas. Na passagem, afirma:

A lógica é parecida com a da dona de casa, que vai a mais de um sacolão por exemplo e sempre encontra um ou outro produto com preço menor do que na concorrência. No caso dos bancos pode valer mais a pena ainda comparar, porque o custo do dinheiro costuma variar bastante (Jornal Nacional, 2015).

No começo da passagem, o plano está aberto, então a câmera começa a se movimentar, passando pelas bancas com legumes e frutas, percorrendo um caminho como se fosse alguém indo ao encontro do repórter, em um plano mais fechado (Figura 3). Em nenhum momento o repórter interage diretamente com o ambiente, mantendo o olho e o corpo voltados para a câmera, deixando com que a ação seja integralmente comandada pelo cinegrafista. Nesse caso, a passagem cumpre um caráter pedagógico, em que os mediadores escolhem 
um espaço que serve como metáfora para explicar um conceito econômico considerado mais complexo para o telespectador comum. O movimento de câmera simula a ideia de um telespectador que se encontra no mesmo ambiente do repórter. No começo, o plano mais aberto permite uma noção mais abrangente do espaço, inclusive com a presença dos consumidores fazendo compras. Durante a passagem, a câmera se aproxima do repórter, como se fosse o telespectador chegando perto do mediador para entender melhor a informação. O movimento propicia uma aproximação entre telespectador e mediador, que mantém o olho no olho como forma de conexão direta com a audiência.

Figura 3. Passagem de Ricardo Soares, em 2015.

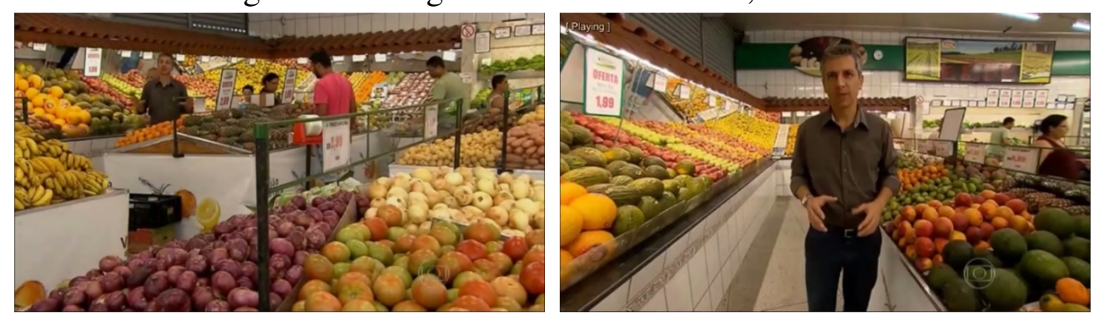

Fonte: Jornal Nacional, 2015.

O aumento do uso de movimentos de câmera demonstra que com o passar do tempo ocorreu uma mudança nas regras do jogo, o que Bourdieu chama de habitus. No início do telejornalismo, principalmente na década de 70 , a câmera parada era o padrão hegemônico. A partir da segunda metade da década de 80, é possível notar a inserção do movimento de câmera como parte dos códigos visuais na gravação de uma passagem. A incorporação desse elemento não-verbal é mantida até hoje, ainda que persista a predominância do quadro parado. No exemplo acima da passagem contemporânea, a câmera ainda ganha um reforço no status de sujeito, ao passo que conduz a ação da narrativa, servindo de elo ativo na aproximação entre repórter e audiência. Citamos uma passagem histórica onde o movimento poderia contribuir para a passagem, mas não queremos dizer que mover a câmera seja uma necessidade ou que vá sempre acrescentar algo ao produto final. Pelo contrário, na amostra há diversos exemplos de passagens onde o quadro parado demonstra de fato ser a melhor opção. 
A análise demonstra que não estamos diante de uma trajetória em que na ponta inicial está uma câmera imóvel e na ponta final está uma câmera frenética, sempre em movimento. A mudança que ocorreu foi a superação de uma rigidez, de um habitus que preconizava o menor movimento possível da câmera. A nova configuração permite que repórter e cinegrafista avaliem caso a caso e decidam, quando entenderem pertinente, o uso do movimento a favor da narrativa. Tratar o movimento de câmera como regra seria criar uma nova imposição desnecessária, como já ocorre em alguns telejornais mais populares em que a câmera nervosa é uma exigência. O caminho que está se formando é do equilíbrio, onde repórter e cinegrafista, cientes das opções que dispõem, podem fazer escolhas de acordo com as necessidades e limites da situação: o movimento é pertinente? Ajuda na compreensão da informação? Contribui de forma interessante para a performance do repórter? São perguntas que podem ajudar a nortear a decisão, eximindo os profissionais de incorrer no erro de usar o movimento de câmera como mero enfeite visual sem propósito.

\section{Repórter (en)quadrado}

O plano é o menor fragmento distorcível da natureza, segundo definição o cineasta soviético Sergei Eisenstein (1990). Para o autor, cada plano é descritivo e isolado em significados, mas quando combinados formam novos sentidos, novos contextos para serem interpretados. A essa combinação podemos dar o nome de "montagem" ou "edição", sendo o primeiro mais associado ao cinema e o segundo mais utilizado no universo televisivo. Segundo Nogueira (2010), a composição do plano respeita a organização dos elementos presentes diante da lente, como personagens, figuras, espaços, objetos, fundos, entre outros. Ao analisar o enquadramento das passagens, buscamos identificar padrões dominantes e o surgimento de possíveis rupturas ao longo do tempo. Nogueira (2010) afirma que a escolha de um plano é na maioria das vezes uma adesão deliberada a um programa criativo, em que o uso de determinados tipos de plano evidencia um estilo coletivo adotado por um grupo social.

Para análise das passagens, os enquadramentos foram classificados em três tipos, apontados como dominantes no telejornalismo por Gutmann (2012): primeiro plano, plano americano e plano geral. Como primeiro plano, foram considerados os enquadramentos do repórter na altura do ombro, posicionamento que pode ter sentido de proximidade junto à audiência, que é 
interpelada de maneira mais explícita pela postura, assim como pode ter efeito de ênfase argumentativa. Como plano americano, foram considerados os enquadramentos do joelho para cima, na cintura ou um pouco acima da cintura. Indica "distanciamento e formalidade entre as partes do diálogo de modo a demarcar autoridade do mediador em relação ao enunciado" (Gutmann, 2012, p. 244). Como plano geral, foram considerados os enquadramentos em que o repórter aparece de corpo inteiro, permitindo uma ampla visão do local onde ele está inserido. O plano permite a inclusão do mediador no contexto comunicativo, mostrando com mais abrangência o lugar dos acontecimentos.

Entre as passagens históricas, verificamos a forte presença do plano americano, utilizado em $90 \%$ dos casos. Em segundo lugar, aparece o plano geral, com $7 \%$, e em terceiro, o primeiro plano, usado em apenas 3\% das passagens. Importante destacar que os casos de plano geral só aparecem com frequência no final da década de 80, mais especificamente entre 1987 e 1990. Nas passagens contemporâneas, o plano americano permanece como padrão dominante, mas com menor participação: $75 \%$ dos casos. O plano geral ganha mais espaço, com $21 \%$, enquanto o primeiro plano mantém a incidência praticamente estável, com utilização em $4 \%$ das passagens.

Mesmo que tenha perdido hegemonia com o passar do tempo, o plano americano ainda se apresenta como o enquadramento preferencial. Trata-se de uma moldura padrão do momento em que o repórter aparece na reportagem: o repórter memoriza o texto, escolhe o fundo e o cinegrafista de forma automática enquadra o mediador em meio corpo. Os demais planos são opções secundárias, que exigem uma tomada de decisão baseada em intencionalidades, como mostrar melhor o local onde estão (plano geral) ou dar ênfase na posição de autoridade do repórter (primeiro plano).

Ao longo da história do telejornalismo, há imagens ícones, como a tradicional passagem gravada em frente às sedes do poder político. No Brasil, o Palácio do Planalto, em Brasília, sede do Poder Executivo Federal, é um dos cenários mais corriqueiros. Na amostra, identificamos duas passagens captadas com uma distância histórica de 38 anos que apresentam o mesmo cenário e enquadramento. Em 12 de outubro de 1977, a repórter Edilma Neiva fez uma reportagem sobre a exoneração do general Silvio Frota do cargo de Ministro do Exército do governo de Ernesto Geisel. O general, que representava a linha dura da ditadura militar, tinha pretensões de se candidatar à Presidência da República, mas os planos foram interrompidos após a saída do Ministério. 
Já em 08 de outubro de 2015, a repórter Zileide Silva realiza uma reportagem sobre uma reunião da presidente Dilma Rousseff com os ministros para cobrar agilidade na articulação com o Congresso Nacional para a votação dos vetos presidenciais. Nas duas passagens, o enquadramento é praticamente o mesmo, variando o turno (dia em 1977 e noite em 2015) e o formato (passou de 4x3 para 16x9), ampliando o espaço captado nas laterais do vídeo.

Figura 4. Passagens de Edilma Neiva, em 1977, e de Zileide Silva, em 2015.
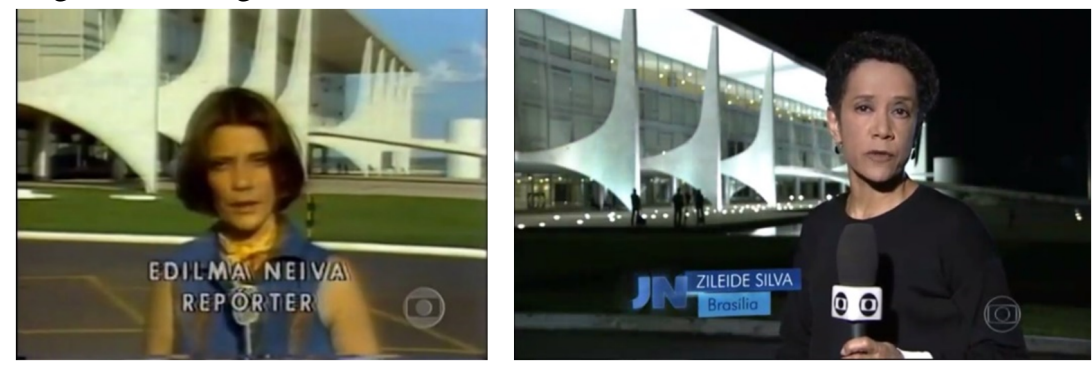

Fonte: Memória Globo, 1977; Jornal Nacional, 2015.

A análise quantitativa aponta que, nos dias de hoje, duas de cada dez passagens exibem o repórter de corpo inteiro, permitindo ao telespectador ter uma dimensão ampla do local onde o mediador está inserido. No dia 24 de outubro de 2015, o repórter Felipe Santana fez uma reportagem sobre mercado imobiliário, com enfoque nos descontos oferecidos para diminuir os estoques das construtoras. Quando a passagem começa, é difícil perceber o repórter, de tão aberto que está o plano. A câmera inicialmente enquadra oito residências de três andares, depois aproxima-se do repórter, que está na sacada do terceiro andar de uma das casas. A passagem tem um corte e, então, a câmera - que estava do lado de fora - passa para dentro da residência e grava o repórter saindo da sacada e entrando na sala, sempre de corpo inteiro, até concluir a passagem (Figura 5).

A análise dos enquadramentos das passagens confirma que o plano americano se consolidou como a opção preferencial para o momento em que o repórter aparece no vídeo. A formalidade e distanciamento, conferidos pelo enquadramento em meio corpo, alimentam a posição de autoridade na relação entre mediador e enunciatário. O habitus, nos termos de Bourdieu (2011), de gravar passagem em plano americano perpassa a história do telejornalismo, 
Figura 5. Passagem de Felipe Santana, em 2015.

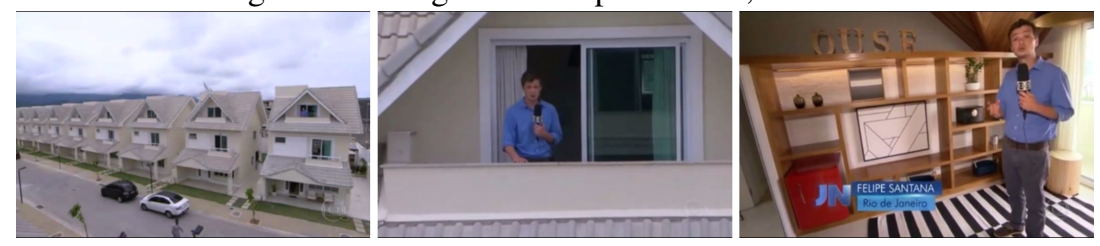

Fonte: Jornal Nacional, 2015.

levando os repórteres dos dias atuais a optarem pelo enquadramento por meio do illusio, um investimento sem pensar nas regras do jogo dentro do campo. Deste modo, postulamos que o enquadramento preferencial estipulado pela cultura profissional no campo do telejornalismo é o plano americano, e todas as tentativas que fogem dessa premissa exigem um grau de esforço criativo e de justificativa, até para obter a aprovação dos demais indivíduos do próprio campo.

No entanto, as mudanças em espaços hegemônicos, como os telejornais de referência, não ocorrem de uma hora para outra. O crescimento do uso de enquadramentos em plano geral é um indício de flexibilização do padrão do plano americano. Entre os profissionais do telejornalismo, as tentativas de sair do modelo histórico e experimentar novas possibilidades normalmente são saudadas, ainda que se encontrem mais associadas a reportagens de conteúdo mais leve.

Nesse processo, um ingrediente não pode ser ignorado: os avanços técnicos. O uso do microfone sem fio deu mais liberdade criativa ao repórter e cinegrafista, que puderam experimentar um distanciamento entre os dois sem estar limitado pelo tamanho do cabo do microfone. No entanto, não são somente as condições técnicas que determinam os enquadramentos. As decisões em campo tomadas pelo repórter e pelo cinegrafista são consequência da cultura profissional e das posições subjetivas de cada profissional, os quais ainda tendem em sua maioria a optar pelo plano americano. De qualquer modo, os resultados das análises indicam que está em andamento um desapego aos padrões, abrindo brechas para novas possibilidades de mostrar o corpo do repórter na tela. 


\section{O tempo da presença}

A inclusão do tempo da passagem como categoria para análise ocorreu a partir da leitura flutuante, momento em que se identificou que nas passagens mais antigas que se teve acesso, era frequente o repórter aparecer muito rapidamente, algumas vezes para dizer unicamente uma frase. Essa característica destoa do que se verificou nas passagens da atualidade, em que o repórter dificilmente utiliza uma frase muita curta para o momento em que aparece no vídeo, geralmente ele desenvolve um raciocínio um pouco mais elaborado. A partir dessa constatação empírica, foi incluída a verificação do tempo médio das passagens.

Diferentemente do que ocorre em outros tipos de imagem, como a pintura e a fotografia, a imagem em movimento tem no tempo uma de suas características fundamentais. Para Nogueira (2010), a duração de um plano não pode ser negligenciada enquanto fator determinante na composição de uma imagem. O tempo no cinema, assim como nos demais textos audiovisuais, é uma "condição intrínseca da sua existência fenomenológica, do sentido da sua interpretação, da sua coerência discursiva e da sua experiência afectiva" (Nogueira, 2010, p. 74). Segundo o autor, há vários fatores que influenciam na duração de uma imagem na tela, como: o tipo de cena (ação, diálogo etc.); a estratégia de montagem; o estilo do realizador; e o gênero narrativo (sequências de ação e sequências dramáticas demandam ritmos diferentes).

De acordo com a análise da amostra de 145 passagens que compõem esta pesquisa, averiguamos que o tempo médio das passagens históricas foi de 15,7 segundos, enquanto nas passagens contemporâneas a média de duração subiu para 19,5 segundos, um acréscimo de 24,2\%. Dois exemplos de passagens históricas demonstram que, no início do telejornalismo, o momento em que o repórter aparece no vídeo poderia ser muito passageiro, praticamente apenas o cumprimento de uma formalidade da aparição do jornalista no local dos acontecimentos. Em 1979, o repórter Aloísio Nascimento (Figura 6) fez uma reportagem sobre o retorno de exilados após a Anistia, em que afirma: "Dulce Souza Maia é a primeira pessoa banida do país que retorna após a aprovação do projeto da Anistia". No ano seguinte, em 1980, Ernesto Paglia (Figura 6), que até hoje integra a equipe de repórteres do Jornal Nacional, realiza uma reportagem sobre a Greve do $\mathrm{ABC}$, em que diz: "Em São Bernardo, os metalúrgicos fazem assembleia e decidem continuar a greve". Nos dois 
casos, as passagens têm em torno de cinco segundos, uma duração difícil de ser encontrada nos tempos atuais.

Figura 6. Passagem de Aloísio Nascimento, em 1979, e Ernesto Paglia, em 1980.
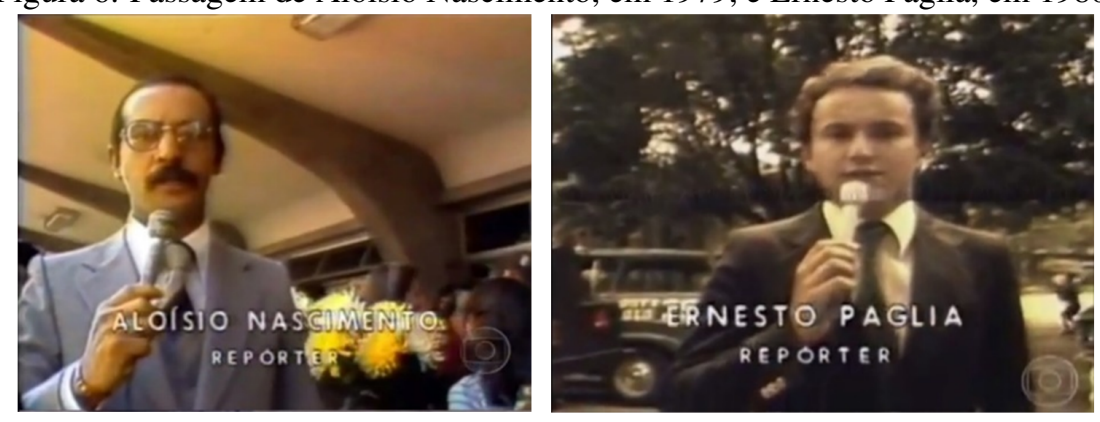

Fonte: Memória Globo, 1979/1980.

$\mathrm{Na}$ amostra das passagens captadas em 2015, a que teve maior duração foi de uma reportagem especial sobre os obstáculos enfrentados por pessoas com deficiências para realizar sua locomoção em grandes cidades. Reconhecemos que reportagens especiais fogem à regra do dia a dia de produção do telejornalismo, permitindo que as equipes possam fazer experimentações na linguagem. De qualquer maneira, a duração dessa passagem é emblemática: são 59 segundos, quase um minuto, tempo suficiente para conceber uma reportagem completa de curta duração. A passagem de Marcos Losekann, exibida no dia 14 de setembro de 2015, foi gravada em duas cidades: a primeira metade em Brasília e a segunda parte no Rio de Janeiro. No início, ao fundo, aparece um dos símbolos da capital federal, o prédio do Congresso Nacional. O repórter está com um globo terrestre na mão, no qual ele aponta com o dedo a localização de Brasília. Ele então aproxima o objeto da câmera, que fica totalmente preenchida pelo globo, o que permite a transição. Quando o objeto se afasta da câmera e retorna para perto do corpo do repórter, ele já se encontra em um dos cartões postais do Rio de Janeiro.

O que mais se destaca quando se comparam as passagens das duas épocas são as funções predominantes em cada período. Nas décadas de 70 e 80 , a função de presentificação, nos termos de Abreu e Lima (2010), em que o repórter precisa mostrar que esteve no local dos acontecimentos, foi muito utilizada. Para mostrar que está no lugar dos fatos, não é preciso muito tempo, uma 
Figura 7. Passagem de Marcos Losekann, em 2015.

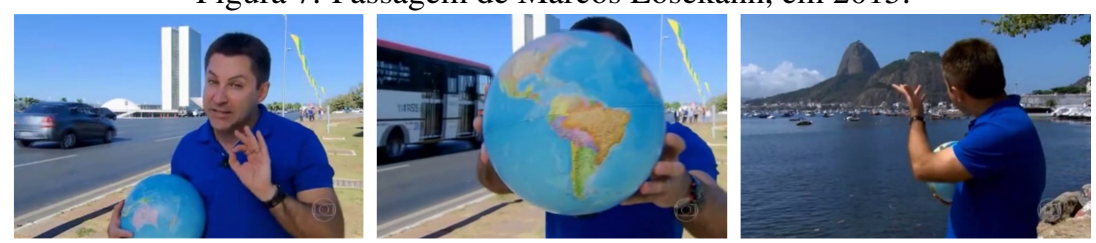

Fonte: Jornal Nacional, 2015.

breve imagem e um texto curto podem atender ao propósito. Já na atualidade, mostrar o repórter no local dos fatos se configura como premissa básica, inerente ao desempenho do repórter. Portanto, no momento mais emblemático de sua participação, que é a passagem, o repórter precisa acrescentar algo mais. É quando entram em cena outras funções mais complexas que a mera presentificação, como a contextualização, a hierarquização e a proposição de juízos interpretativos.

As performances dos repórteres também se tornaram mais elaboradas com o passar do tempo. Parar na frente da câmera para dizer um texto ainda é uma forma de fazer uma passagem, mas se constata um esforço de aprimorar a performance no vídeo. Conforme Gutmann (2012), hoje a postura de autoridade do repórter também se dá pelo desempenho de um papel de sujeito que vivencia os fatos e por isso está autorizado a falar sobre eles. Para demonstrar essa vivência diante da câmera, interagir com o ambiente e outros personagens, o repórter necessita de mais tempo. Mergulhar a coisa narrada no corpo do narrador, como afirma Benjamin (1996) é um desafio constante dos repórteres, e a narrativa televisiva que sai deste mergulho dificilmente conseguirá demonstrar as marcas de autoria em apenas cinco segundos. É preciso mais tempo.

\section{Corpo em movimento}

Para observarmos o corpo do repórter no momento da passagem, estabelecemos um contraponto entre o corpo parado e o corpo em movimento. Ainda que estejamos cientes de que entre essas duas situações opostas há nuances, como a diferença entre um corpo que aponta um local e um corpo que anda pelo espaço, para fins metodológicos da análise quantitativa nos detivemos a 
identificar se há ou não movimento do repórter no momento em que ele aparece no vídeo. Entre as passagens históricas, verificamos que em $70 \%$ dos casos o repórter se manteve parado, contra 30\% de passagens com repórter em movimento. Nas passagens contemporâneas, a situação ficou mais equilibrada: em $46 \%$ dos casos, há movimento do corpo, enquanto que em $54 \%$ das passagens o repórter não se movimenta.

Assim como ocorreu com a observação do uso do movimento de câmera, percebemos que na segunda metade da década de 80 cresceu a incidência de passagens em movimento. A repórter Sandra Passarinho, que faz parte da equipe atual de repórteres da Rede Globo, aparece na amostra de passagens históricas coletadas para pesquisa. Selecionamos dois exemplos de passagens da jornalista, um da década de 70 e outro da década de 80. Em 1978, ela realizou uma passagem sobre a expectativa para o nascimento do primeiro bebê de proveta do mundo. Com exceção de leves inclinações com a cabeça, a repórter não realiza qualquer tipo de movimento, nem mesmo os habituais gestos contidos com mão, que tradicionalmente acompanham as passagens em plano americano em que o repórter se dirige integralmente para a câmera. $\mathrm{O}$ braço que não segura o microfone permanece imóvel, solto, ao longo do corpo da repórter. Também não há qualquer menção corporal ao hospital citado no texto, que está logo atrás da jornalista.

Uma década depois, em 1987, a mesma repórter grava uma passagem sobre o avanço da AIDS no Brasil e no mundo, adotando uma postura diferente. No texto, enfatiza dados mundiais e nacionais sobre casos e contaminação. Durante a passagem, atravessa uma faixa de pedestres em um dia chuvoso, em que quase todos os pedestres estão de guarda-chuva, menos a repórter. Comparando as duas passagens, constatamos comportamentos opostos em relação ao movimento do corpo. No primeiro caso, a inércia impera, observamos um corpo praticamente imóvel de onde sai uma voz que informa. O corpo está no local do acontecimento, mas não interage minimamente com o ambiente. Já no segundo caso, o corpo está em constante movimento, mas carece de justificativa para tal ato. Por qual razão a repórter atravessa uma faixa de pedestres em um dia de chuva, sem proteção, para falar dados mundiais e nacionais sobre o avanço da AIDS? O andar parece sem propósito, até porque o ponto de chegada, o outro lado da rua, não diz nada.

É interessante resgatar, para compreendermos melhor essa diferença, um depoimento do repórter Lucas Mendes (2001) para Coutinho (2012). Segundo 
Figura 8. Passagens de Sandra Passarinho, em 1978 e em 1987.



Fonte: Memória Globo, 1978/1987.

o jornalista, que atuou como correspondente internacional da Rede Globo, houve um período em que a direção da emissora, incomodada com a imagem predominante do repórter parado na tela, exigiu que todos os repórteres caminhassem nas passagens. O pedido foi atendido, mas logo a direção percebeu que havia cometido um erro e voltou atrás, pois também era incômodo ver o repórter de TV sempre em movimento durante a passagem.

$\mathrm{O}$ levantamento entre as passagens atuais demonstra um equilíbrio entre o uso do movimento do corpo do repórter. Ainda há a predominância do repórter parado na frente da câmera, a consolidação de um habitus, nos termos de Bourdieu, que indica o modo padrão do repórter dar seu discurso do momento da passagem. Entretanto, o aumento de casos em que o repórter se movimenta na passagem mostra que o mediador está mais integrado ao acontecimento, não apenas dizendo que esteve no local dos fatos, mas os vivenciou, como sujeito da ação. Becker (2005) afirma que, por meio da passagem e da mediação do repórter, o telespectador tem a oportunidade de pisar no território da atualidade. Atualmente, além de pisar, é possível percorrer e interagir no território dos acontecimentos, e o corpo do repórter é o instrumento para isso.

Em 16 de outubro de 2015, a repórter Cecília Malan, correspondente da Rede Globo em Londres, realizou uma reportagem sobre a transformação de espaços abandonados, alguns subterrâneos, em imóveis residenciais e comerciais. No momento da passagem, ela apresenta um novo ambiente, um antigo banheiro público subterrâneo transformado em uma cafeteria (Figura 9). Para isso, ela dá alguns passos, contorna a entrada do espaço e permite que a câmera mostre o lugar, fazendo menção ao local através de gestos e do olhar, e por fim, ao terminar o texto, começa a descer as escadas que dão acesso à cafeteria, que será então mostrada no prosseguimento da reportagem. Nesse 
caso, os movimentos foram justificados, tiveram um propósito, e a passagem serviu ainda de elemento de conexão entre conteúdos diferentes na mesma reportagem. Por meio do corpo do repórter, nos aproximamos do local do acontecimento e adentramos o espaço de interesse. Passagens como a de Cecília Malan exploram melhor as possibilidades do corpo do mediador, servindo de instrumento para a condução da narrativa.

Figura 9. Passagem de Cecília Malan, em 2015.

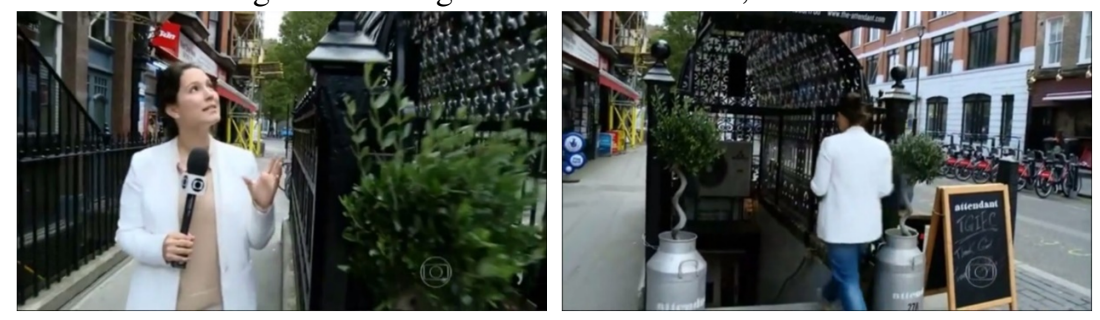

Fonte: Jornal Nacional, 2015.

O "clássico", no caso da passagem, é o repórter e câmera parados, com enquadramento em plano americano. Um modelo que, como demonstra a análise quantitativa dessa pesquisa, permanece hegemônico. Em reportagens de conteúdos mais difíceis de exercer a criatividade, como política, por exemplo, extrapolar nos movimentos do corpo do repórter e da câmera podem acabar em um resultado de mau gosto e carente de propósito, a não ser a fuga do padrão, sem que para isso se encontre motivos para a ruptura. Entendemos que, em espaços paradigmáticos, como telejornais de referência, a mudança é gradual, exercitada em reportagens de temas mais brandos, que aos poucos contaminam reportagens de temas intermediários até respingar em assuntos mais sérios.

O esforço que ocorreu no final da década de 80 , de implementar um repórter em movimento a todo custo, encontrou uma zona de maior equilíbrio na atualidade, em que é preciso buscar justificativas para a interação do corpo do repórter com o ambiente. A experiência profissional na área nos demonstrou que os cinegrafistas mais experientes costumam recorrer a uma frase clássica, ao se defrontarem com repórteres jovens que querem insistentemente incorporar movimento às passagens: "não dá para andar do nada ao lugar nenhum". 
Existe sabedoria no argumento, ou seja, é preciso que os códigos visuais estejam claros para que o movimento encontre sentido no cenário.

Goffman (1985) pontua uma operação fundamental na representação dos papéis que os indivíduos executam diariamente: a manipulação do espontâneo. A habilidade de representar exige o emprego da dose certa de espontaneidade para evitar a descrença do público. Acreditamos que o mesmo se aplica à passagem do repórter, que precisa articular com sabedoria os códigos visuais, como o movimento do próprio corpo, para que a representação permaneça envolta de credibilidade e contribua para a comunicação com a audiência, não sendo um obstáculo à assimilação do conteúdo.

\section{O detalhe do figurino}

A aparência física do jornalista de TV é um importante recurso de autoria, que pode ajudar a criar efeitos de aceitação, simpatia e credibilidade. Para Rosário (2009), a moda é a construção de aparência que se consubstancia em discursos, sobretudo midiáticos, aumentando a capacidade de fala do corpo. Ao estudar sobre o figurino no telejornalismo, Aquino (2011) analisa o formato mais conservador de noticiar os fatos, em que se busca sobriedade para transmitir valores de credibilidade e "causar a impressão de distanciamento do público e da forma de falar cotidiana" (p. 99). A autora ainda reforça que diversos aspectos da imagem do apresentador ajudam a compor um conjunto de significados para a audiência, como a aparência física, a postura corporal, o penteado, o vestuário, o comportamento contido, a voz pausada e o uso impecável da linguagem verbal.

Há uma relação próxima entre a forma de se vestir e a intenção de se comunicar com os outros. O figurino é um componente importante para a formação da imagem de credibilidade do indivíduo, e "a televisão, como lente de aumento para todas as características do ser, amplia também essa percepção da indumentária como comunicação, como colaboradora no papel de construção da imagem de credibilidade" (Aquino, 2011, p. 76). Como elemento representativo das mudanças que podem ter ocorrido no telejornalismo no que diz respeito à forma com que o repórter se apresenta visualmente para o público, escolhemos o uso da gravata entre os repórteres homens. Para Martins (2015), a gravata nos telejornais é "uma metáfora para a seriedade e a vigilância que os profissionais devem ter para o bom exercício de suas funções” (documento 
eletrônico não paginado). No entanto, a autora pondera que o jornalismo televisivo está, de certo modo, afrouxando a gravata, apostando em um modelo mais solto, com menos formalidade.

Os resultados das análises apontam uma mudança significativa com o passar do tempo. Nas passagens históricas, $71 \%$ dos repórteres homens estavam de gravata, enquanto que apenas $29 \%$ decidiram não usá-la. Já nas passagens coletadas em 2015, a gravata apareceu em apenas $20 \%$ dos casos, contra $80 \%$ dos repórteres homens que optaram por gravar sem o acessório. Houve uma inversão de preferência, migrando de um uso praticamente obrigatório para uma frequência eventual.

Uma passagem que ilustra a imposição do uso da gravata nas primeiras décadas do telejornalismo é de 1986, gravada durante a cobertura da explosão da nave espacial Challenger, que incendiou 73 segundos após o lançamento, causando a morte dos cinco tripulantes. Nos dias seguintes ao desastre, o então correspondente da Rede Globo nos Estados Unidos Paulo César Araújo gravou uma passagem na praia, de terno completo (Figura 10), para falar sobre a busca dos destroços da nave especial naquela parte do mar. A formalidade do vestuário destoa do ambiente onde o repórter se encontra. Na maior parte do tempo, a orla não está ocupada por outras pessoas, apenas no final da passagem é possível ver um morador caminhando de camiseta e bermuda bem próximo ao mar. Possivelmente, se fosse nos dias atuais, o repórter dispensaria o uso da gravata e talvez até do paletó, optando por uma camisa arremangada.

Em 24 de outubro de 2015, o correspondente da Rede Globo nos Estados Unidos também gravou uma passagem sobre um tipo de desastre. A reportagem era sobre um furacão que chegou a ventos de mais $300 \mathrm{~km} / \mathrm{h}$ no oceano, mas perdeu força ao atingir a costa da América do Norte. O repórter gravou a passagem em primeiro plano em uma rua de Nova York, onde é possível ver em um fundo desfocado o tráfego de pessoas (Figura 10). Diferentemente do correspondente de 1986, que usou terno completo na praia, Helter Duarte optou por vestir um tipo de jaqueta mais informal.

A gravata é um código visual que expressa um sentido, o qual se modificou com o passar do tempo. Nos anos 1970 e 1980, o acessório contribuía para construção de uma imagem de credibilidade e autoridade. Com o passar do tempo, o sentido passou por ajustes, podendo, dependendo da circunstância, expressar excesso de formalidade e um distanciamento do interlocutor. Atualmente, o repórter conquista a autoridade menos pelo seu posto e mais 
Figura 10. Passagens de Paulo César Araújo, em 1986.

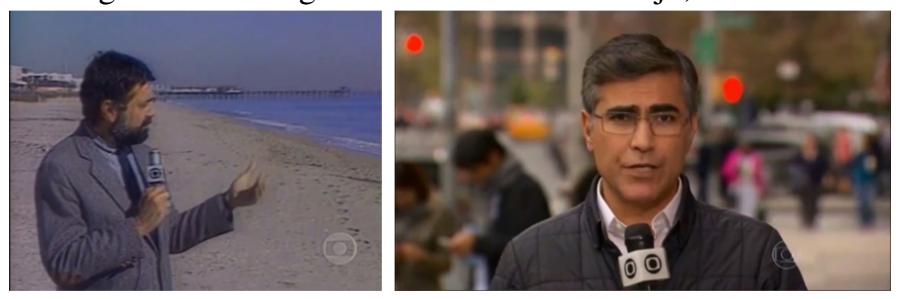

Fonte: Memória Globo, 1986; Jornal Nacional, 2015.

pela sua atuação como ser social que vivencia e testemunha os fatos. Essa persona televisiva precisa encontrar pontos de semelhança com o público a que se reporta, para assim conquistar sua confiança e empatia.

A tomada de decisões sobre o figurino, que é um dos códigos visuais operantes no momento da passagem, também exige o acionamento de uma audiência presumida. Com isso, o repórter mapeia antecipadamente um público para o qual se dirige e ajusta sua aparência para fortalecer o elo com o interlocutor. Deste modo, verificamos que a aparência rígida, sóbria, representada pela gravata, se restringe a situações mais específicas, como por exemplo a cobertura política. $\mathrm{O}$ acessório, que no início do telejornalismo era item quase obrigatório, hoje é utilizado por apenas dois de cada dez repórteres homens. A maioria constrói sua própria imagem não mais se apropriando de um item de vestuário que confere credibilidade, mas sim optando por figurinos adequados a cada circunstância, em que o telespectador possa se identificar, desenvolver empatia e assim acreditar nos papéis e cenários construídos para mediar a informação.

\section{Apoio do grafismo}

O jornalista, mesmo que queira muito, não mostra ao público o real na sua condição primária, no seu estado de origem. Considerando que toda a apreensão da realidade é mediada, o que é possível fazer é operar o real. Cabral (2012) afirma que os jornalistas não reproduzem o real, mas sim o interpretam. A notícia se apresenta como um simulacro do real, um relato possível, entre tantos, do real. Para a autora, os profissionais que trabalham com a construção da notícia, ao escolherem um fato e não outros, ao narrar de um 
jeito e não de outro, estão manipulando a realidade. Segundo Cabral (2012), a manipulação está presente em todo ato comunicativo e deve ser destituída de seu caráter demoníaco. A partir desse entendimento, é possível compreender a tecnologia digital como uma ferramenta para que os jornalistas continuem operando a realidade, com alguns aperfeiçoamentos.

A autora entende que a tecnologia está ajudando os profissionais a simularem o real das notícias televisivas em condições mais favoráveis e criativas, ou seja, estão fazendo o que sempre fizeram, no entanto em melhores condições técnicas e tecnológicas. Nos seus estudos dos gráficos no telejornalismo, Cabral (2012) criou o conceito de realidade expandida, uma capacidade ampliada de apresentar, construir e proporcionar a percepção dos sentidos visuais de mundo, de uma forma mais inteligível. A tecnologia digital "cria imagens no computador para mostrar aos telespectadores o que eles jamais veriam, porque não houve ou não tinha como haver a gravação de imagens" (Cabral, 2012, p. 142).

Entre as passagens históricas, não foi encontrado nenhum tipo de grafismo nas passagens, como já era de se imaginar devido às limitações técnicas da época. Portanto, $100 \%$ das passagens históricas não utilizaram grafismo. Entre o material da atualidade, $13 \%$ das passagens tem algum tipo de grafismo, contra $87 \%$ de casos que não possuem. Como se pode perceber, ainda se trata de uma ferramenta pouco utilizada, e que também depende do avanço tecnológico das emissoras de televisão para ser implementada. Emissoras com departamento de grafismo menos estruturado podem ter sérias dificuldades para implementar com competência o grafismo nas reportagens diárias.

No dia 16 de outubro de 2015, o repórter Bruno Laurence preparou uma habitual matéria sobre o Campeonato Brasileiro de Futebol. O uso da tabela do campeonato para ilustrar a posição dos times é um recurso comum nesse tipo de reportagem. Desta vez, parte da tabela foi utilizada dentro da passagem, em que se percebe o repórter interagindo com a tabela virtual, que se sabe ter sido inserida posteriormente, durante a edição. Já em 14 de setembro de 2015, o grafismo foi utilizado durante uma reportagem sobre a seca no sudeste brasileiro, que prejudicou o abastecimento de água. Como havia chovido recentemente, a matéria mostrou que muitas pessoas estavam aproveitando para armazenar em casa a água da chuva. A repórter Daniela Golfieri gravou a passagem em uma ponte sobre uma represa. A arte é utilizada para demonstrar a quantidade de chuva que havia caído nos últimos dias, e como 
as pessoas que tivessem condições de armazenar água da chuva poderiam ter sido beneficiadas. Em um trecho da passagem, a repórter afirma: "Em apenas cinco dias, choveu aqui 133 milímetros. E sabe o que isso significa? Que nesse espaço onde eu estou, com um metro quadrado, caíram 133 litros de água" (Jornal Nacional, 2015).

Figura 11. Passagem de Bruno Laurence e Daniela Golfieri, em 2015.
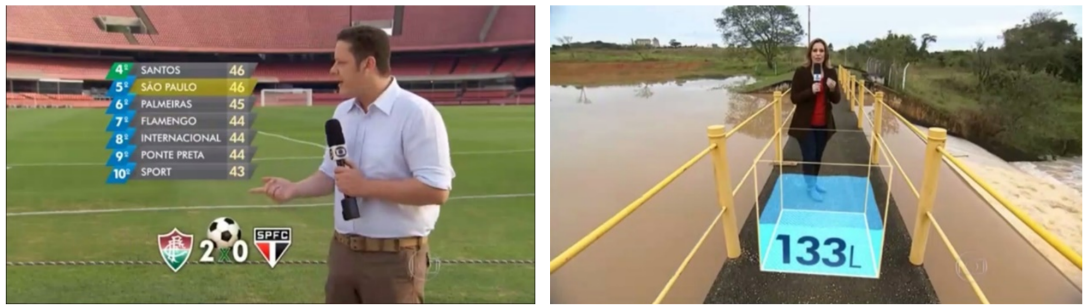

Fonte: Jornal Nacional, 2015.

No dia 24 de outubro de 2015, o repórter Phelipe Siani fez uso do grafismo na passagem de uma reportagem sobre o uso de contêineres em diversas situações do cotidiano, como para fazer moradias, prédios e unidades comerciais. Em uma das partes da matéria, são mostrados contêineres que são colocados em um terreno e podem ser usados para fins comerciais, como restaurantes. Para mostrar a mobilidade das estruturas, que podem ser modificadas de lugar, retiradas ou colocadas com relativa facilidade, o repórter faz o uso da tecnologia digital. Durante a passagem é simulada, por meio do grafismo, a inserção de três novos contêineres no espaço, que depois são virtualmente retirados, acompanhando o raciocínio do texto do repórter.

Percebemos que o grafismo se trata ainda de um recurso pouco utilizado (13\%), mas não se pode ignorar que esse tipo de código visual virtual conquistou um espaço em um momento da reportagem até então preservado das interferências da tecnologia. A aplicação do grafismo na passagem acompanha as funções que a tecnologia digital já desempenha no telejornalismo: ajudar o telespectador a compreender melhor uma informação. A tabela virtual do campeonato auxilia o público na identificação das posições dos times e as mudanças que ocorreram na rodada; a caixa d'água virtual deixa mais palpável o quanto se poderia acumular de água com o que choveu nos dias anteriores; e os contêineres que se movem facilmente graças à tecnologia vi- 
Figura 12. Passagem de Phelipe Siani, em 2015.

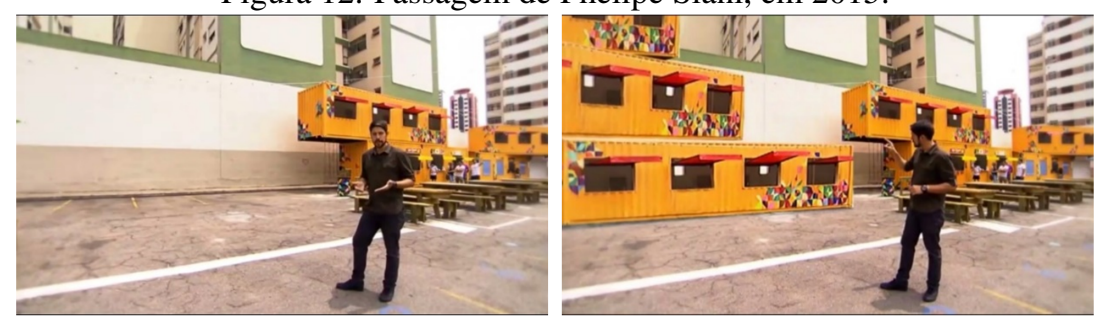

Fonte: Jornal Nacional, 2015.

sam a permitir que o público entenda melhor os aspectos de mobilidade do material.

A performance do repórter diante do vídeo, que tem seu momento emblemático na gravação da passagem, ganha um apoio tecnológico, com a inserção do grafismo como código visual complementar. Entretanto, trata-se de um recurso em fase de implementação, dentro de um telejornal, o Jornal Nacional, que tem à disposição recursos tecnológicos e de pessoal que permitem o uso do grafismo com mais abundância. Em telejornais menos expressivos ou de emissoras com recursos mais limitados, a aplicabilidade do grafismo na passagem se tornaria um desafio tecnológico mais difícil de ser superado, o que restringe seu uso. São caminhos novos abertos pelo uso da tecnologia, que para serem considerados válidos, vantajosos e legítimos, precisam em primeiro lugar estarem à serviço da informação.

\section{Considerações finais}

Ao longo desta pesquisa, buscamos aproximar dois universos que insistem em permanecer distantes: o espaço acadêmico e o mercado de trabalho. Nosso foco foi o repórter de televisão, uma peça-chave do telejornalismo que se encontra às margens dos estudos acadêmicos de televisão. Este trabalho chancela a importância no telejornalismo de um narrador que possa transmitir valores essenciais para a audiência, como confiabilidade e competência para mediar a informação. Não há como pensar em uma reportagem de televisão sem um narrador presente, que ajude a entender os fatos, que tenha capacidade de interagir com as fontes, com o espaço e também com o telespectador. 
O jornalismo é alicerçado em um conjunto de valores compartilhados entre os profissionais que o operam e seu público. Entre esses valores, um se destaca: a credibilidade. Sem ela, o jornalismo deixa de existir. No telejornalismo, a figura do repórter é o principal instrumento desse valor, pois se trata do sujeito que mais se aproxima da notícia para obter a legitimidade necessária para narrá-la. A passagem, momento em que o repórter aparece na TV, é um carimbo de credibilidade. É nesse instante que o narrador ganha forma, recebe um nome, é inserido dentro do tempo e do espaço, e também se expõe à audiência. Na passagem, o jornalista se apresenta, mostra seu rosto, o lugar onde se encontra e fala diretamente com o telespectador.

Para se comunicar, assim como em qualquer situação de interação de indivíduos na vida cotidiana, o repórter representa um papel, que precisa ser acreditado pelo seu público. Desse modo, a passagem pode servir para o bem ou para o mal. Pode fortalecer o elo de credibilidade entre narrador e audiência e contribuir para o entendimento da informação. Por outro lado, se executada de forma inapropriada, com uma performance pálida ou carregada de exageros, o repórter perde pontos de credibilidade, difíceis de serem resgatados por melhor que seja o todo da narrativa.

A passagem é a assinatura audiovisual do repórter de televisão, um elemento que praticamente nasceu junto com o telejornalismo e tudo indica que continuará sendo um momento-chave, em que o telejornalismo se mostra ao público como sujeito que tem o compromisso de conduzir o telespectador pelo cotidiano compartilhado na televisão. A amostra de 145 passagens, tanto de reportagens históricas (de 1969 a 1990) como contemporâneas (exibidas em setembro e outubro de 2015), permitiu a observação de padrões dominantes e das mudanças que ocorreram ao longo da história do telejornalismo.

Com base nos resultados das análises, podemos afirmar que nos dias de hoje, quando o repórter aparece na TV, ou seja, na passagem, há uma preferência por manter câmera e repórteres parados, enquadrados em plano americano, próximos do local dos acontecimentos, proferindo um discurso com tempo médio de aproximadamente 20 segundos e apresentando-se com um figurino mais informal. Entretanto, é preciso pontuar as transformações verificadas ao comparar o telejornalismo da atualidade com aquele praticado nas primeiras décadas da televisão.

Ainda que o quadro parado seja predominante, tanto o repórter como a câmera estão se movimentando mais atualmente. Segundo a amostra histórica, 
em 30\% das passagens o corpo do jornalista ocupava o espaço através de movimentos. Hoje em dia, a incidência aumentou para quase metade dos casos (46\%). O cinegrafista, com o passar do tempo, também se permitiu explorar mais o espaço através de movimentos de câmera, assumindo um papel de sujeito que interage com a performance do repórter. Entre as passagens históricas, o movimento de câmera foi constatado em $32 \%$ da amostra, enquanto nas passagens contemporâneas o índice subiu para 46\%. As análises confirmam um aumento de performances mais dinâmicas, mas com uma característica importante: os movimentos não podem ser um fim por si só, devem estar acompanhados de uma justificativa, ainda que sutil, que os torne plausíveis e detentores de sentido dentro da narrativa.

O plano americano, mesmo que permaneça dominante, perdeu força ao longo da história do telejornalismo, cedendo espaço para enquadramentos que contemplam o corpo inteiro do repórter e uma visão mais ampla do lugar dos acontecimentos. Nos anos 70 e 80, o plano americano, em que o repórter é enquadrado um pouco acima ou abaixo da cintura, era utilizado em $90 \%$ das passagens. Nos dias atuais, o uso caiu para $75 \%$ dos casos. Por outro lado, o plano geral, em que o repórter aparece de corpo inteiro ganhou força: passou de apenas $7 \%$ nas passagens históricas para $21 \%$ nas passagens contemporâneas.

A duração das passagens passou de uma média de 15,7 segundos para 19,5 segundos, um indicativo de que o momento em que o repórter aparece no vídeo se complexificou. Atualmente, não basta o repórter dizer uma frase curta apenas para mostrar que está perto do fato, como ocorreu em algumas passagens históricas que integram a amostra desta pesquisa. Estar no território dos acontecimentos é condição elementar para o repórter de televisão, que precisa agora utilizar o momento que se dirige diretamente para audiência para enriquecer a narrativa, contextualizando e interagindo de forma mais contundente e atraente com o espaço que o rodeia. E para isso, é preciso mais tempo.

As análises ainda indicaram que o figurino do repórter passou pela mais expressiva mudança. Para avaliar esse aspecto, utilizamos como parâmetro o uso da gravata entre repórteres homens, um indicativo de formalidade e sobriedade. Nas reportagens históricas, a gravata foi usada em $71 \%$ das passagens. No entanto, nas passagens contemporâneas, a utilização do acessório despencou, ficando restrito a apenas $20 \%$ da amostra. Se no começo do telejornalismo, a gravata era item obrigatório, hoje é um acessório dispensável, 
restrito a reportagens mais formais. Prevalece o bom senso de se adequar ao lugar onde o repórter está, livre da imposição de um pedaço do vestuário que não é mais garantia de credibilidade.

Por fim, o trabalho buscou quantificar a presença de grafismo na passagem, um elemento novo verificado em algumas reportagens durante as observações iniciais do objeto. Por fatores de ordem tecnológica, o artegrafismo está ausente nas primeiras décadas do telejornalismo. Na amostra contemporânea, houve a incidência do recurso gráfico em 13\% das passagens. Ainda que sejam casos mais isolados, atualmente o grafismo é utilizado como ferramenta para aprimorar a narrativa do repórter, contribuindo para uma ilustração mais inteligível de aspectos da reportagem, sem fazer sombra ao elemento principal da passagem, que é o próprio repórter em diálogo direto com a audiência. É possível afirmar que há uma tendência de que o recurso passe a ser usado com mais frequência, desde que cumpra a função de auxiliar o repórter durante a passagem.

Os resultados permitiram um mapeamento dos estilos do repórter de TV, que tem na performance uma ferramenta importante para estabelecer um elo com a audiência. Também é preciso destacar que este trabalho, ao se aprofundar no estudo das performances do repórter televisivo, coloca em evidência a importância do corpo e da voz de um narrador para articular a informação na televisão. Os primeiros registros do telejornalismo já indicavam a necessidade de um sujeito para organizar, presenciar e contar as histórias do cotidiano, um papel que permanece fundamental no tratamento das notícias na atualidade.

O tempo passou, as tecnologias e formas de consumo do audiovisual mudaram, as câmeras estão mais aprimoradas assim como a qualidade da imagem da televisão evoluiu. Em meio a essas transformações, o repórter de TV tem um espaço garantido, constituindo-se como um sujeito insubstituível na reportagem, capaz de conferir credibilidade, personalidade, criatividade e humanidade para os relatos. Estes resultados são apenas os primeiros passos de um percurso que não se esgota neste estudo. É preciso avançar mais na investigação dos elementos visuais presentes na participação do repórter no telejornalismo.

Mesmo que faça performances, decore textos, ensaie movimentos e expresse emoções por meio do corpo e da voz, o repórter de TV não é, nem nunca será, um artista. Ele é jornalista e como tal deve se portar, dando prioridade à informação, fazendo uso das ferramentas que dispõe para aprimorar 
a execução de seu ofício, mantendo os valores éticos e seu dever de verdade. Nas primeiras décadas do telejornalismo, ainda ecoando a rigidez da locução radiofônica, é possível perceber um repórter sóbrio e sério diante da lente da câmera, que assume tal postura em busca de legitimação através da credibilidade transmitida. Hoje em dia, a busca pela naturalidade é mais presente nas passagens, onde o repórter como testemunha dos fatos tenta assumir um papel de contador de histórias. Nem sempre, o profissional acerta o tom, especialmente quando em nome da pretensa criatividade e graciosidade, se vê muito mais uma performance exagerada em cena do que um jornalista que conta e contextualiza fatos.

A televisão pode despertar uma sedução traiçoeira, inclusive nos profissionais que nela atuam. No momento em que o repórter de TV se preocupa mais em "estar bem no vídeo" do que estar bem informado, uma parte do jornalista que há nele está morta. A performance bem executada deve estar sempre à serviço da informação, sem nunca suplantar os princípios deontológicos do jornalismo. Precisamos investigar melhor nossas práticas profissionais, mapear nossos erros, viajar pelo passado, presente e futuro para apontar os caminhos possíveis.

\section{Referências bibliográficas}

Abreu e Lima, L. (2010). Por uma gramática da reportagem: uma proposta de ensino em telejornalismo. Dissertação (Mestrado em Comunicação). Universidade Federal de Pernambuco, Recife.

Aquino, A. (2011). Casal nacional: significações do corpo e do figurino no telejornalismo. Dissertação (Mestrado em Comunicação midiática: práticas sociais e produção de sentido). Universidade Federal do Rio Grande do Norte, Natal. Disponível em http://repositorio.ufrn.br:8080/jspui/han dle/123456789/16399. Acessado em 10 de setembro de 2015.

Aquino, A. (2011). Moda e telejornalismo: o papel do figurino na construção da imagem de credibilidade do jornalista de televisão. Revista Temática, Ano VII, (03), Março. Disponível em http://www.insite.pro.br/. Acessado em 20 de dezembro de 2015. 
Becker, B. (2005). A Linguagem do Telejornal: um estudo da cobertura dos 500 anos do Descobrimento do Brasil. Rio de Janeiro: E-papers Serviços Editorias.

Benjamin, W. (1996). Sobre arte, técnica, linguagem e política. 7ed. 10a reimpressão. São Paulo: Brasiliense. (Obras Escolhidas, vol. 1).

Bourdieu, P. (2011). A economia das trocas simbólicas. $7^{\text {a }}$ edição. São Paulo: Perspectiva.

Brasil, A. (2012). Telejornalismo imaginário: memórias, estudos e reflexões sobre o papel da imagem nos noticiários de TV. Florianópolis: Insular.

Cabral, Á. (2012). Manipulação, simulação e infoimagem: a realidade expandida no telejornalismo. In F. Porcello; A. Vizeu \& I. Coutinho (orgs.). O Brasil (é)ditado. Coleção Jornalismo Audiovisual. 1. Florianópolis: Insular.

Coutinho, I. (2012). Dramaturgia do telejornalismo: a narrativa da informação em rede e nas emissoras de televisão de Juiz de Fora-MG. Rio de Janeiro: Mauad X.

Eisenstein, S. (1990). A forma do filme. Rio de Janeiro: Jorge Zahar Editora Ltda.

Goffman, E. (2013). A representação do eu na vida cotidiana. $19^{a}$ edição. Petrópolis-RJ: Editora Vozes.

Gutmann, J. (2012). Formas do telejornal: um estudo das articulações entre valores jornalísticos e linguagem televisiva. Tese (Doutorado em Comunicação e Cultura Contemporâneas). Universidade Federal da Bahia, Salvador. Disponível em https://repositorio.ufba.br/ri/bitstream/ri/8806/1/J uliana\%20Gutmann.pdf. Acessado em 15 de agosto de 2015.

Jornal Nacional. Site do. Disponível em http://g1.globo.com/jornal-nacional/ index.html. Acessado em 10 de julho de 2015.

Machado, A. (2000). A televisão levada a sério. São Paulo: Editora Senac.

Martins, M. (2015). Quando o jornalismo tira a gravata. Observatório da Imprensa, edição 874. Disponível em http://observatoriodaimprensa.com. br/televisao/quando-o-jornalismo-tira-a-gravata. Acessado em 08 de dezembro de 2016. 




Memória Globo, Site. Disponível em http://memoriaglobo.globo.com. Acesso em 04 de maio de 2015.

Memória Globo. (2004). Jornal Nacional: a notícia faz história. Rio de Janeiro: Jorge Zahar Ed..

Nogueira, L. (2010). Manuais de Cinema III: Planificação e Montagem. Covilhã: LabCom Books. Disponível pela internet no site http://www.livro slabcom.ubi.pt/pdfs/nogueira-manuais_III_planificacao_e_montagem. pdf. Acessado em 15 de novembro de 2015.

Pinto, I. (1997). A dramatização no telejornalismo. Revista Famecos (07), novembro. Pontifícia Universidade Católica do Rio Grande do Sul. Porto Alegre.

Porcello, F. \& Ramos, R. (2012). Âncora na TV - A celebração do discurso do poder. In F. Porcello, A. Vizeu \& I. Coutinho (orgs.). O Brasil (é) ditado, Coleção Jornalismo Audiovisual, vol.1. Florianópolis: Insular.

Ramos, F. (2012). A imagem-câmera. Campinas: Papirus.

Revista Exame. (2015). Em 2013, 97,2\% dos lares contavam com televisão. Reportagem publicada no dia 30 de abril, disponível no endereço eletrônico http://exame.abril.com.br/tecnologia/noticias/em-2013-97-2-dos-la res-contavam-com-televisao, acessado em 10 de novembro de 2015.

Rezende, G. (2000). Telejornalismo no Brasil: um perfil editorial. São Paulo: Summus.

Rosário, N. (2004). A estética discursiva da tevê e a (des)configuração da informação. Caderno IHU Ideias, ano 2 (25).

Rosário, N. (2009). Corporalidades audiovisuais: transcendência e ludicidade. Trabalho apresentado ao Grupo de Trabalho Comunicação e Cultura. XVIII Encontro da Compós, junho, PUC-MG, Belo Horizonte-MG.

Rosário, N. \& Damasceno, A. (2014). A Prescrição do Corpo Televisivo: Interdição, Autoria, Repetição e Trans-aparência. Revista Comunicação Midiática (Online), 9(2): 68-81, maio/agosto. Bauru/SP.

Rossini, M. (2006). O lugar do audiovisual no fazer histórico: uma discussão sobre outras possibilidades do fazer histórico. In A. Lopes; M. Velloso \& S. Pesavento (Org.). História e Linguagens: Texto, imagens, oralidade e representações, (vol. 1, pp. 113-120). $1^{\text {a }}$ edição. Rio de Janeiro: 7 Letras. 
Vizeu, A. (2005). O lado oculto do telejornalismo. Florianópolis: Calandra.

Zamin, A. (2014). Jornalismo de referência: o conceito por trás da expressão. Revista FAMECOS, 21(3): 918-942, set.-dez. Porto Alegre. Disponível em http://revistaseletronicas.pucrs.br. Acessado em 15 de janeiro de 2016. 